\title{
Chapter 7 \\ Fragmented Geographies of Education: Institutions, Policies, and the Neighborhood
}

\author{
Tim Freytag and Samuel Mössner
}

Opening up easier access to and participation in education is highly important as it enables and fosters social integration, qualification, and empowerment. Against this backdrop, educational opportunities and educational justice appear to be central and permanent concerns of social and educational policies. However, it has to be acknowledged that educational opportunities have never been equally distributed, whether geographically or between societies, social groups or individuals. In fact, educational opportunities depend not only on individual skills and conditions, but also on various kinds of circumstances. Consequently, it definitely matters where, and under which conditions, somebody lives and grows up. It is not just the education system, but also family background, the neighborhood, and other factors, that build the framework for educational opportunities. This complex set of elements, which can be addressed as multifold educational settings, have an important impact on the educational biographies and the subsequent pathways of people seeking to enter the labor market.

Educational settings, both in and out the school environment, not only affect one's educational opportunities, but may also result in structural disadvantages and barriers. Restricted educational opportunities make it harder to achieve higher qualifications, to find well-paid jobs, and to live in a comfortable and secure situation with a middle or high socioeconomic status. In this light, educational institutions and settings not only contribute to social integration and advancement, but also have the potential to reinforce social exclusion or discrimination. Following the seminal work of Bourdieu and Passeron (1977), it can be argued that educational institutions

\footnotetext{
T. Freytag $(\bowtie)$

Institute of Environmental Social Sciences and Geography, University of Freiburg,

Freiburg, Germany

e-mail: tim.freytag@geographie.uni-freiburg.de

S. Mössner

Institute of Geography, University of Münster, Münster, Germany

e-mail: moessner@uni-muenster.de
} 
tend to reproduce and legitimize social and cultural inequalities. However, opinions diverge concerning education's role for and within societies. All in all, we can note that this role is at least ambivalent, often unclear, and certainly highly contested in ongoing academic, political, and wider societal debates.

Our aim in this chapter is to explore educational inequalities that can be observed across sociodemographic and territorial categories. We will focus on the question of how and to what extent educational settings produce and reinforce educational inequalities. Further, we will take a look at political programs and initiatives aimed at improving educational opportunities and related settings at a local scale. This type of area-based intervention in educational landscapes has become increasingly important - often with education being framed according to the New Public Management paradigm and within the neoliberal logics of competition, rankings and best practices. In our study, we focus on the educational landscape in Freiburg, Germany, which has been formed by policies and initiatives operating at national, regional and local scales.

In the first part of this chapter, we sketch out the education system in Germany, which reveals major spatial disparities resulting from the decentralized organization of the education sector, in order to identify and discuss the emergence and reproduction of educational inequalities. We point out that demographic, economic, and ethnic or cultural characteristics of the students and their family background may intersect, and substantially enhance or restrict their educational opportunities. We argue that transfers - in particular, from primary to secondary, and from secondary to higher education or vocational training - are structured by educational barriers. Moreover, we underline the need to integrate social and educational policies more efficiently within the framework of an area-based approach to local intervention. Drawing upon the national program entitled "Lernen vor Ort" (local learning), which is intended to enhance networking and cooperation between educational actors and institutions at the local scale, we give an example of an innovative initiative that has the potential to combine educational and social policies. In the second part, we take a closer look at the educational landscape in Freiburg and explore the educational infrastructures and inequalities that exist there, against the backdrop of general patterns of education in Germany. We draw upon a series of biographical interviews conducted with adolescent students who are confronted with severe educational barriers, to show that they often face various intersecting disadvantages, related to both in-school and out-of-school settings, which are very difficult to overcome. Further, we critically assess how the "Lernen vor Ort" program was carried out and implemented in the initiative entitled "Lernen Erleben in Freiburg" (LEIF). We conclude with a discussion of the limited potential of "Lernen vor Ort" and the LEIF initiative to transform the educational landscape and to work against both educational inequalities and the prevailing fragmented geographies of education. 


\section{Geographies of Education in Germany}

\section{Education System}

The education system in Germany is rather complex as a result of its decentralized structure, with each of the 16 federal states being in charge of education policies and planning. However, some overarching structures exist, which we will sketch out in this section (Fig. 7.1). For babies and young children, there are noncompulsory public and private childcare facilities, such as crèches, nursery schools, and daycare centers. In general, compulsory education starts at the age of six (though this may vary between the ages of five and seven, depending on the child's individual development) with primary school, which usually comprises grades 1-4 and in some cases also grades 5 and 6 . The subsequent transfer to secondary-level education involves selection, as the students are split up between several types of institution. Grammar schools specialize in qualifying students for higher education (Gymnasium up to grade 13, or in a few cases grade 12). Lower and intermediate secondary schools put more emphasis on vocational training (Hauptschule and Realschule up to grade 9 or 10). Grades 5-6 serve as an orientation stage (Orientierungsstufe) to facilitate transfers between these different types of school, although only a small proportion of students actually change from one type of school to another during these 2 years. As transfers from lower to intermediate secondary school, or from intermediate secondary school to grammar school, are rather complicated, and do not occur very often, the Gesamtschule was created as an integrated comprehensive school that combines lower secondary, intermediate secondary, and grammar schools with the aim of facilitating transfers in both directions according to the students' abilities and achievements. In addition, there are specialized schools which are designed for students with learning difficulties or other special needs.

After completing lower or intermediate secondary school, students may start an apprenticeship program combined with vocational school (usually 3 years, but only 2 years for people who have completed grammar school), or they attend specially designed programs at vocational schools without an integrated apprenticeship. If they leave school without being adequately qualified to start an apprenticeship or a job, students enroll in the transition system (Übergangssystem), which is a set of programs that school leavers can attend in order to obtain such a qualification (Raffe, 2008). The transition system is particularly important for school leavers who are still subject to the rules for full-time compulsory schooling. This ends after 12 years of schooling, of which the last 3 years may be a vocational training. The rules may vary depending on the legislation of the German state concerned. The majority of adolescents who enter the transition system have either left school without an educational qualification, or they hold a qualification from a lower secondary school. This is formally acceptable but often not competitive enough, given the limited options for entering the labor market and the high percentage of school leavers and young adults with better qualifications. In the realm of higher education, 


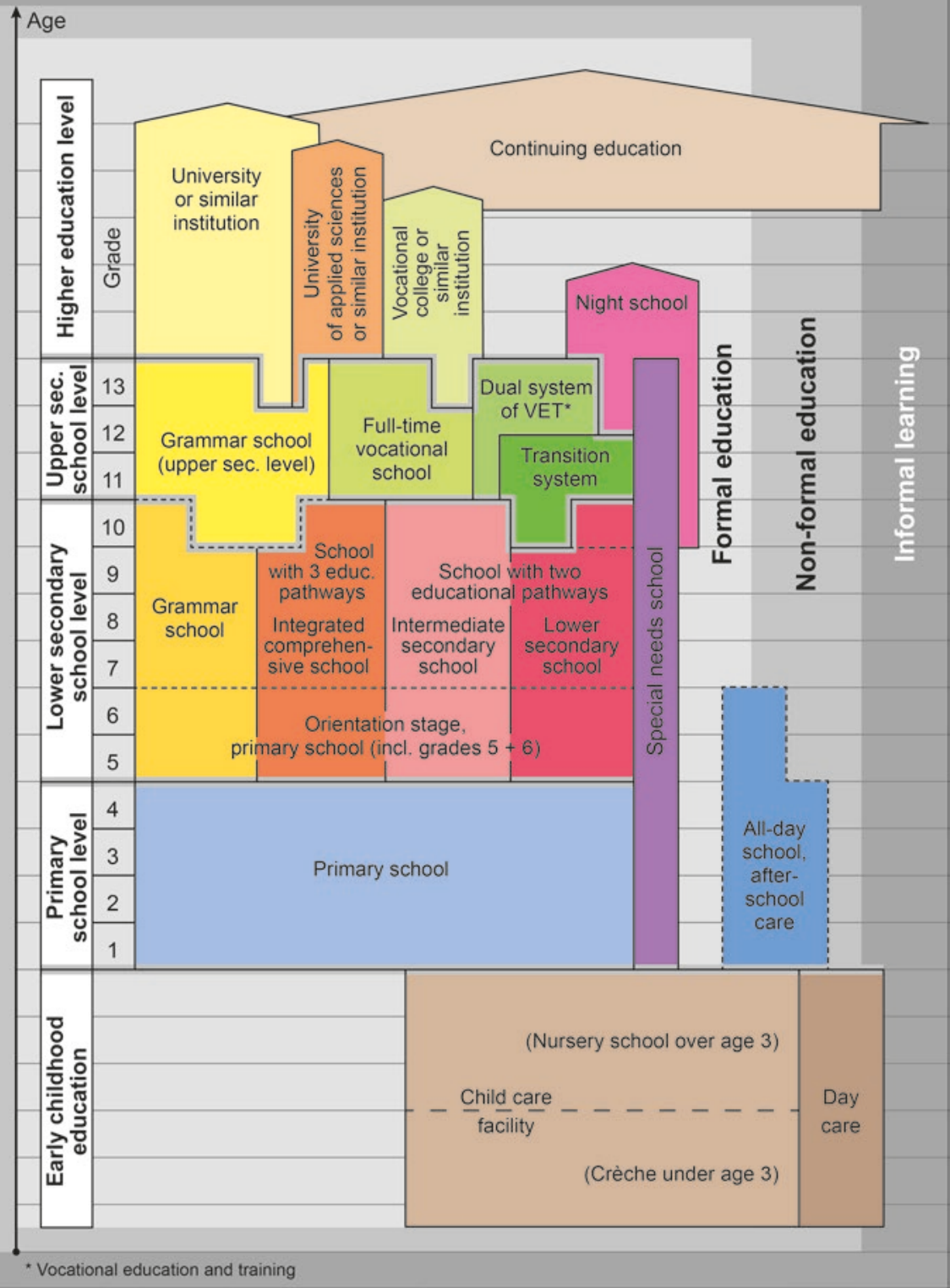

Fig. 7.1 Education system in Germany. Adapted from Maaz et al. (2020, p. XX). Copyright 2020 by wbv Publikation. Adapted with permission 
universities, universities of applied sciences, vocational colleges, and similar institutions offer study programs leading to the award of a bachelor's or master's degree. Students can be admitted to such institutions if they hold the appropriate entrance qualification (Abitur) after having completed grade 12 or 13 at a grammar school or another specialized institution in secondary education. However, education is not limited to formal education provided by primary and secondary schools and institutions of higher education, but also includes nonformal education and informal learning.

\section{Educational Inequalities}

A set of educational inequalities is documented in educational statistics that give information about educational infrastructures and access to education, educational participation and success, transfer to superior educational institutions, and educational attainment. Educational inequalities are widely distributed across society and vary over time and space. However, the assessment and analysis of educational inequalities depends on the existence of suitable indicators and the availability and quality of appropriate data. Thus, it can be assumed that educational statistics reflect existing educational inequalities to some extent, but do not necessarily give the full picture.

In Fig. 7.2, we provide an overview of educational attainment in Germany. With regard to the completion of different types of secondary schools, all three age groups show a trend toward more women and men gaining qualifications from a grammar school or an intermediate secondary school, whereas the number of people completing lower secondary school is declining. This can be understood as a progressive inflation of educational qualifications, in the sense that more people hold superior qualifications than in previous generations (Meusburger, 1998). Moreover, there is a gender gap in respect of completing grammar school that has shifted and reversed within the past three decades. Consequently, in 2018 men were overrepresented in the age group of 60-65 years, whereas women were overrepresented in the age group of 30-35 years. Concerning the number of people with academic degrees, the reversal of the gender gap observed in the case of grammar schools is confirmed. Further, an increasing number of men do not hold an academic or vocational qualification.

The distribution of educational qualifications is characterized by inequalities not only across the categories of age and gender, but also with regard to students with an immigrant background. This is a German census category that applies to all individuals who do not have German citizenship by birth or who have at least one parent who does not have German citizenship by birth. These students are clearly underrepresented in the educational pathways leading to qualifications from grammar schools and institutions of higher education, as well as vocational schools. The same is true for students whose parents have a poor economic and educational background (Baumert \& Schümer, 2002; Maaz et al., 2020). These trends suggest that 


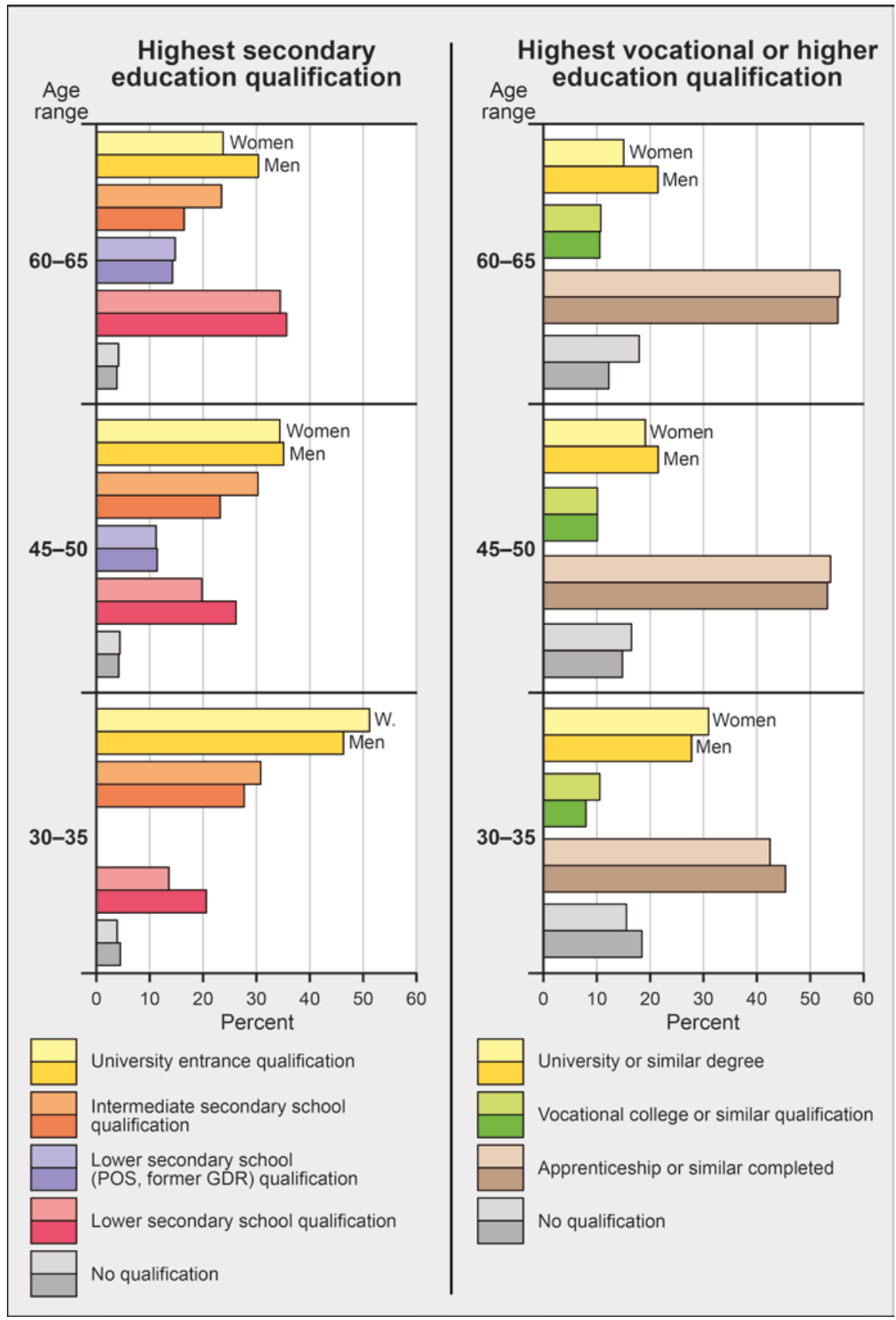

Fig. 7.2 Educational attainment of the population in 2018 by age groups and gender (in percent). Adapted from Maaz et al. (2020, p. 67). Copyright 2020 by wbv Publikation. Adapted with permission 
there are structural barriers at work that constrain educational chances for students from specific backgrounds. Thus, education fosters social reproduction in the ways that Bourdieu and Passeron (1977) identified and explained in their studies conducted in France some 50 years ago. Social reproduction through education can be regarded as a general trend that has been prevalent in most countries and societies for many centuries, and which still persists in Germany and many other countries, as PISA and other international studies have shown (European Commission, 2019, pp. 24-34; van Zanten, 2005).

Educational inequalities are produced and reinforced by the principles of selection and exclusion that have shaped the education system in Germany. Although there are ongoing initiatives to work for flexibility and open up more alternatives in the different federal states (Länder), the German education system is still relatively rigid and contributes to aggravating the stratification that disadvantages students with an immigrant background or from families with limited socioeconomic and educational resources (OECD, 2020). An important element in the separation process consists in the strategies and practices of parents who want to send their children to a "better school" and find ways to circumvent the catchment areas for primary schools (Noreisch, 2007). In North Rhine-Westphalia, a state where free choice of primary school was established in 2008, Ramos Lobato and Groos (2019) have observed that social stratification is being reinforced by the system of free choice. As Ramos Lobato (2019) points out, the networks created among parents of children who attend preschool day-care facilities are crucial for practices relating to choice of primary school, which in turn determine children's educational opportunities and enhance social reproduction.

The most significant steps in the educational selection process are the moments of transition between different types of school, notably after completion of primary school (Becker \& Reimer, 2010). Compared with international standards and examples, the German practice of separation after primary school, which is very early in a student's educational career, has important consequences for children's educational chances and professional perspectives (OECD, 2020). Significant life choices are made when the parents decide which school they will send their children to after completion of primary school at the age of 10-11 years. Although formally the decision depends on the student's educational attainment, the choice of school appears to be a matter of preference on the part of his or her parents, reflecting their educational aspirations and consequently reproducing social status and stratification.

Another important step in a person's educational career is the transfer from secondary school to a higher education institution or to an apprenticeship and vocational training. Despite the fact that at first glance the education system in Germany offers manifold career options, a significant number of students drop out of secondary education, or complete it without passing the necessary exams, and are therefore excluded from admission to apprenticeships. These adolescents can join a multitude of private and public institutions that offer additional educational support. The transition system involves a wide range of opportunities that do not necessarily qualify students for employment, but which are aimed at improving their chances of successfully enrolling in a vocational training course. The transition system is often 
described as a transitional space between general education and vocational training (Schmidt, 2011), and is thus managed by a complex constellation of different public and private organization and institutions, with sometimes unclear responsibilities and prerogatives. Political awareness of the transitional system and thus of adolescents who are at risk of dropping out of the education system is relatively new. For the first time in 2006, the national education report's compilers mentioned this important and discrete part of the education system in Germany, even though the infrastructure, institutions and organizations had existed for decades. Formerly, political and institutional actors alike simply ignored students who dropped out of formal education.

In a spatial dimension, educational inequalities can be assessed at different scales. In Fig. 7.3, we show that there are considerable inequalities between Germany's federal states. This is a result of education being conceived as the responsibility of the 16 Länder, each of which has its own education system and sets its own priorities. Whereas one group of states sticks to an extended traditional system (i.e., predominant separation between grammar school, intermediate secondary school, and lower secondary school), other states adopt a system with two more or less extended educational pathways (i.e., a less rigid, but still existent, separation of students in secondary education). Consequently, there are important differences at the state level in terms of the types of schools providing secondary education. The provision of lower or intermediate secondary schools is limited to those states with an extended traditional system. Here, the state of Bavaria stands out with a very high share of lower secondary schools (over 40\%). Today, schools with two or three educational pathways are the most important type in the other states. Grammar schools exist in all 16 states and are particularly prevalent in the city-states of Hamburg and Berlin.

Education inequalities also exist between rural and urban spaces, and at a smaller scale within cities, urban districts, and neighborhoods. Researchers into geographies of education who draw upon data from educational statistics (Butler \& Hamnett, 2007; Meusburger, 1998) have uncovered spatial disparities with regard to educational infrastructures, access to education, and educational attainment, taking into account political and economic restructuring processes (Hanson Thiem, 2009; Holloway \& Jöns, 2012). It can be assumed that educational inequalities are not exclusively produced at school, but also in the out-of-school environment, meaning family, friends, and the neighborhood (Baur, 2012). How to react to educational inequalities is one of the major challenges for social and educational policies aimed at establishing equal living conditions all over Germany, as aspired to in the basic constitutional law (Grundgesetz für die Bundesrepublik Deutschland [Basic Law of the Federal Republic of Germany], 2020, Art. 72 II GG). 


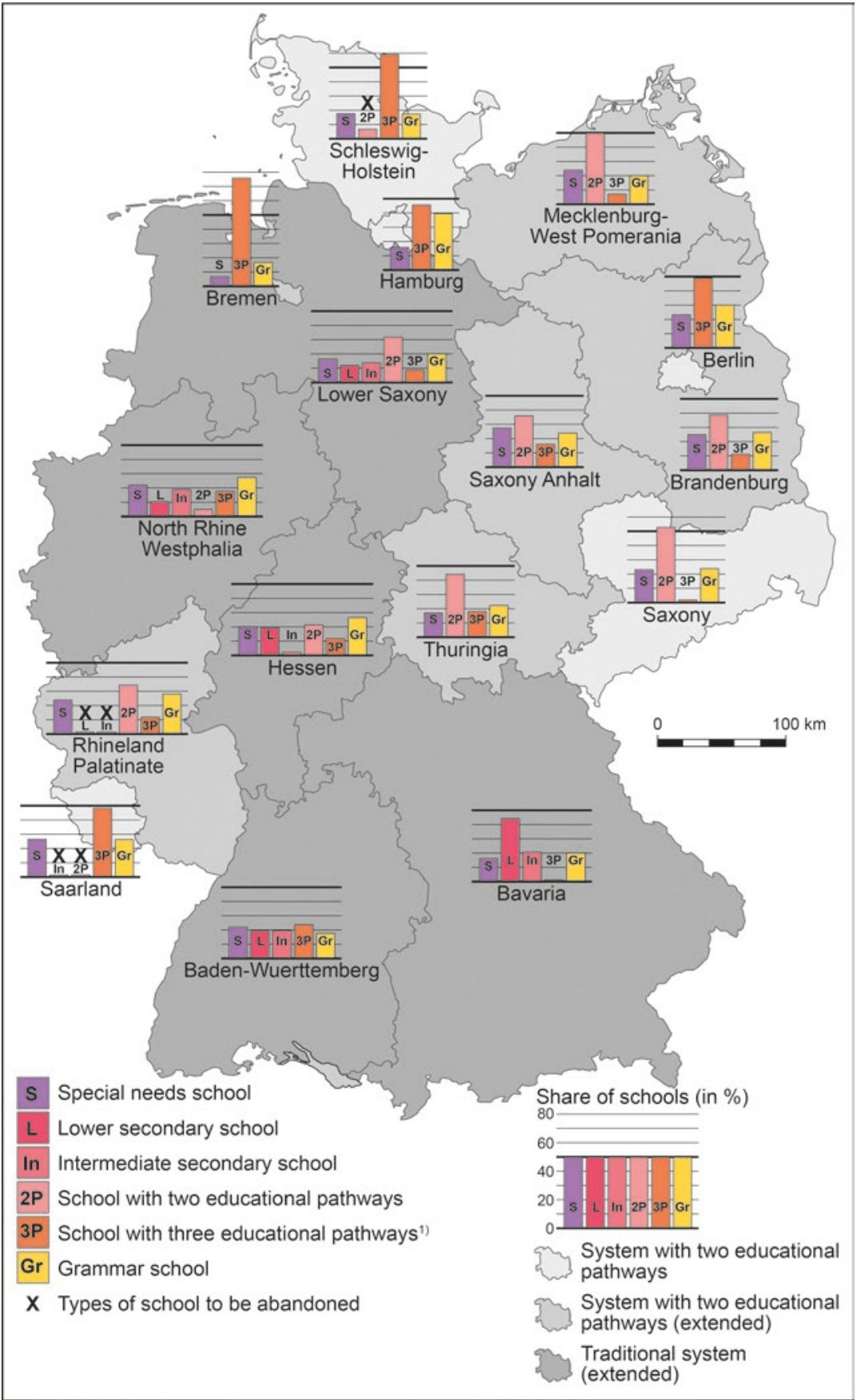

Fig. 7.3 Secondary schools in 2018-19 by types of school and states (in percent). Adapted from Maaz et al. (2020, p. 109). Copyright 2020 by wbv Publikation. Adapted with permission 


\section{Educational and Social Policies That Operate Separately}

The expansion of the education sector in the 1970s with the establishment of a large number of new schools, colleges, and universities all over the country considerably improved the educational infrastructure and facilitated access to education for wider parts of the population - in particular, for people living outside the larger cities in rural or peripheral areas. This was an important step towards the establishment of equal living conditions and educational opportunities in (Western) Germany. However, throughout the following decades, education policies have contributed to the perpetuation and consolidation of the German education system, rather than to stimulating progressive reforms, although the education sector undoubtedly plays a crucial role in recent urban social policies: Education is one of the most important prerequisites for social mobility and equality in the knowledge society. Moreover, schools are important locations in which significant changes are stimulated, and schools have privileged access to a wider society, with students and their parents acting as multipliers. These aspects make the education system and in particular schools an important resource for local social development programs. Yet, the social initiatives and programs that have been launched in recent decades too often stop at the school gates.

At first sight, it seems paradoxical that social initiatives and programs are not systematically integrated into educational institutions, as the education system in Germany is mainly based on public schools. Public schools potentially play an important and privileged role in fostering and supporting social integration measures (Schreiber, Stein, \& Pütz, 2016), in particular when it comes to the teaching of 'social scripts' and 'language as part of cultural integration' (Esser, 2001). Experts share a broad consensus concerning the importance of the acquisition of German language skills for the successful integration of immigrants and their children into society. And yet, daily practice at most schools belies this. Why, for example, is German as a subject taught in classes where children with German as a second language sit together with native speakers, despite the fact that, unlike the rest of the class, these students need special help with language acquisition? In many cases, teachers of German lack special skills and do not get further training in order to adequately respond to this challenge. It is clear that this double taskteaching German for native speakers and giving support to students who do not speak German well-can easily be too much for the teachers. It seems as if political discussions and decisions in the realm of social policies and integration do not include one of the most important elements: education and schools. And, even worse, schools and educational institutions suffer from cuts in government spending with severe impacts on equality and social justice. Consequently, the responsibility for a good education for their children appears to rest on the parents, and on the financial and other resources that they are able and willing to mobilize.

Despite its manifold connections to other policy fields-social policies, integration, inclusion, welfare, and work - the education sector has remained in a state of political and institutional isolation for many years, and has more or less continued 
to contribute to the production and reproduction of societal stratification by practices of selection and exclusion. The rigid educational pathways determine the students' life chances, beginning at a very early age, and have consequences for societal structures for years to come. Education and the school system are important pillars of Germany's conservative welfare system (Esping-Andersen, 1990), with its corporatist-statist character aimed at the conservation of status in society and across generations, and fostering equality rather than equity. Unsurprisingly, people with a working-class background are underrepresented in higher education. In 2016, 52\% of students at public universities had an academic family background (Middendorff et al., 2017). With social and educational policies operating apart from each other, it seems to be very difficult, if not impossible, to break the vicious circle of selfreinforcing dynamics in the interplay between social and educational reproduction. In other words, the education system primarily serves the interests of the upper and middle classes.

\section{Towards Integrated Approaches-Social Policies That Take the Education System into Account}

The education system and its various institutions continue to be important arenas where the consequences of political decisions made in other social areas are witnessed and lived. It can be observed that schools and other educational institutions tend to give only limited and privileged access to individuals and communities, which makes them a potential target and key priority for social policies and urban planning. In the urban context, however, most of the various programs and interventions that deal with the great social challenges in the early twenty-first centuryimmigration and integration, social exclusion, poverty and welfare-are still too often disconnected from schools and education.

Yet, there is something to be learned from the development of urban policies over the last 30 years, not only in Germany but in many other countries as well. With the roll-back of public welfare, the manifold deregulations and privatizations in urban contexts (regarding, for instance, the housing market and welfare provision) leading to precarious living conditions and social exclusion have increased. This became dramatically evident in France, for example, when the peripheries of French cities were burning in protest against the government's systematic ignorance of the situation in large-scale housing areas and the housing estates of the 1960s and 1970s. Unlike other areas in the cities, these were particularly exposed to the negative consequences of urban neoliberalization (Castel, 2009). New planning methods, models, and approaches were urgently needed. As a consequence, during the 1990s, policymakers promoted social urban policies aimed at reducing social exclusion and poverty. Although similar approaches had existed before, these new integrated urban policies encompassed a wide range of approaches-material interventions in urban spaces, as well as social measures that included the empowerment of citizens 
and participatory approaches. These policies' most revolutionary aspect was the fact that they started to bring the neighborhood level to the forefront of political intervention (Astleithner \& Hamedinger, 2003; Smith, Lepine, \& Taylor, 2007). Although planning policies had previously predominantly followed a sectoral rationale, actors now implemented them in a certain area and sought to integrate a larger group of actors from various sectors.

The turn from sectoral to spatial urban policies and toward area-based approaches has its beginnings in the context of urban policies at the EU level (Silver, 1994). These were soon followed by a series of national programs intended to integrate a wide range of administrative sectors, including new actors and governance principles, and to open up opportunities for an innovative format of communicative planning that integrated civil society into the planning process. Since then, many European cities have integrated such development programs (Donzelot, 2007; Parkinson, 1998; Walther \& Günther, 2007). The area-based approach has made it possible to consider schools and their representatives as important actors in the neighborhoods. However, it has proved difficult to integrate schools as partners into the new programs due to different rationales, time constraints, and bureaucratic obstacles.

In 2009, the "Lernen vor Ort" (local learning) initiative was launched by the Federal Ministry of Education and Research (BMBF) jointly with the Bertelsmann Foundation and other foundations in Germany. Its purpose was to support local municipalities by providing a suitable framework for a more coherent management of the fragmented education sector. At first it seemed as if policymakers had finally identified and addressed the missing link between social and urban policies with their focus on the neighborhood, on the one hand, and education policies, on the other hand. The program was part of the new agenda to enhance educational attainment and included local monitoring of existing (public and private) actors and institutions. Policymakers explicitly tried to bring together all local resources in order to better understand the education system's selective and exclusionary practices and mechanisms. By doing so, they applied a territorial approach that seemed similar to previous experiences in the context of new spatial urban policies. They clearly stated that they were targeting cities and regions whose residents were confronted with educational possibilities and failures. Consequently, the new program's premise was that educational decisions were made on an individual level but framed in the particular context of the educational landscape's local and regional configuration. The initiative therefore provided funding to municipalities in order to monitor and develop a more transparent and coherent educational landscape.

A particular focus of the "Lernen vor Ort" initiative was on the management of life-long learning, and therefore specifically on the transition between different educational levels. The aim was to better understand why some transitions "successfully" led to the next level of education, whereas others failed, and-in the worst case-students dropped out of the system. The urgent need to implement political measures was evident from the high numbers of students in the transition system (see section on Educational Inequalities in this chapter). In the context of local integration and social support, the transition system plays a crucial role. In 2008, the 
national education report stated that on average $50 \%$ of German adolescents in the transition system leave it after only 3 months, having either successfully applied for a job or started a vocational training. By comparison, those with an immigrant background, and thus a higher need for integration, leave the system after an average of 17 months (Klieme et al., 2008). Furthermore, 60\% of all adolescents who are currently seeking support in order to gain access to the German job market are people without German citizenship or whose parents came to Germany from another country (Klieme et al., 2008, p. 11). This structural imbalance not only underlines the important role the transition system plays for various social urban policies, but also indicates that differences between successful and unsuccessful educational biographies are steadily increasing as a result of ongoing social fragmentation. Accordingly, national policymakers have tried to present a platform on which life-long learning can be better managed by using a local approach that integrates and supports all other social welfare, integration, and support initiatives.

The "Lernen vor Ort" program provides financial means to help establish better local management of the educational infrastructure, quantitative and qualitative monitoring of the various measures, better information and consultation, and better insights into transitions from one educational level to another, and in particular into the challenges and obstacles that determine the chances for successful participation in the educational system (Brümmer et al., 2016). Given the long tradition of selection and separation in the German education system, shaped by transitions from one level to another, the new focus of "Lernen vor Ort" was quite extraordinary and innovative. In 2014, after 5 years of funding, the program officially stopped as a national policy. Subsequently, its ideas were pursued-often on a voluntary basisby various actors, including the public administration, foundations, and voluntary organizations.

\section{Empirical Explorations and Observations in Freiburg}

Against the backdrop of the overarching trends sketched out in the previous section, we will now focus on the educational infrastructure and educational participation in Freiburg. Firstly, we give an overview of the local educational landscape; secondly, we point out a set of problems and challenges related to education from the perspective of students in the transition system; thirdly, we analyze the process of institutionalizing "Lernen Erleben in Freiburg" (LEIF), which is a local initiative that was supported by the national "Lernen vor Ort" program. 


\section{Educational Institutions and Educational Participation in Freiburg}

Freiburg is an old university town that serves as a regional center for transport, commerce, and public administration. The city is located in Southwestern Germany in the federal state of Baden-Württemberg, and has more than 226,000 inhabitants. During the past two decades, Freiburg has experienced a considerable population growth $(22 \%)$ as a result of increasing numbers of German and non-German inmigrants (mainly students, work migrants, and refugees aged between 18 and 25), and a slight increase in the birth rate (Amt für Bürgerservice und Informationsmanagement der Stadt Freiburg im Breisgau, 2019, pp. 2-12).

Freiburg comprises various public and private day-care centers for children, nursery schools, and vocational schools, as well as several universities and other higher education institutions. In this section, however, we focus on primary and secondary education (without vocational training). In the school year 2017-18, Freiburg was home to 62 public schools (with 18,778 students), and 33 private schools (with 5970 students), meaning that $75.9 \%$ of students were enrolled in public schools (Amt für Bürgerservice und Informationsmanagement der Stadt Freiburg im Breisgau, 2019, pp. 176-178). In 2018-19, 55.6\% of students leaving primary school transferred to grammar schools, $31.1 \%$ transferred to intermediate secondary schools, and 23.2\% to other schools (Amt für Bürgerservice und Informationsmanagement der Stadt Freiburg im Breisgau, 2019, p. 178). The share

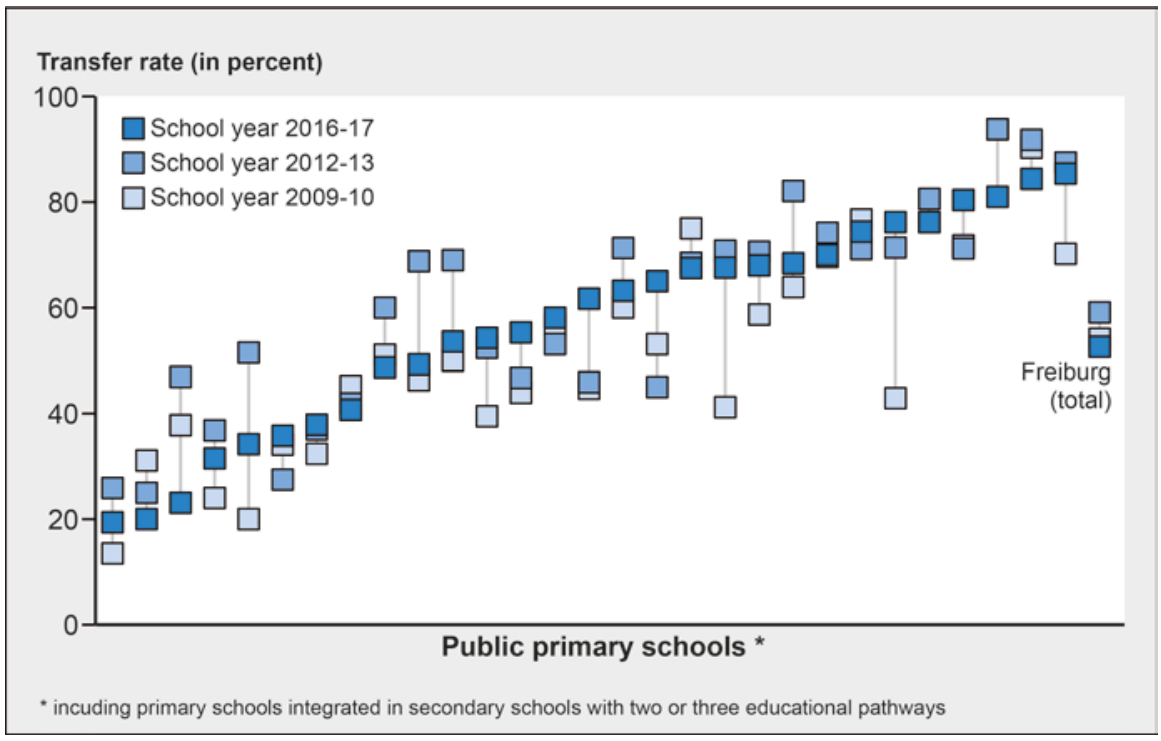

Fig. 7.4 Transfer rates from public primary schools to grammar school in Freiburg in 2009, 2012 and 2016 (Data: Stadt Freiburg, 2017, Tab. C1-10A). Source: Design by authors 
of students who transfer to grammar school in Freiburg is relatively high compared with the overall figures for Germany.

On the level of individual primary schools, there are tremendous inequalities with regard to the range of transfer rates to grammar school. In Fig. 7.4, we show that transfer rates ranged from less than $20 \%$ to over $80 \%$ in the school year 2016-17. Moreover, there are considerable variations at the level of individual schools in the data for 2009-10, 2012-13, and 2016-17. Given a total of fewer than 1000 students per year who transfer from roughly 30 primary schools to one of the grammar schools in Freiburg, the variations from one school year to the next are small in absolute numbers - in particular in the smaller schools. However, Freiburg's total transfer rate has remained constant at around 50\%. It is striking that the City of Freiburg usually does not name individual schools in the official statistics it publishes, but only provides either anonymized or aggregated data. Without more

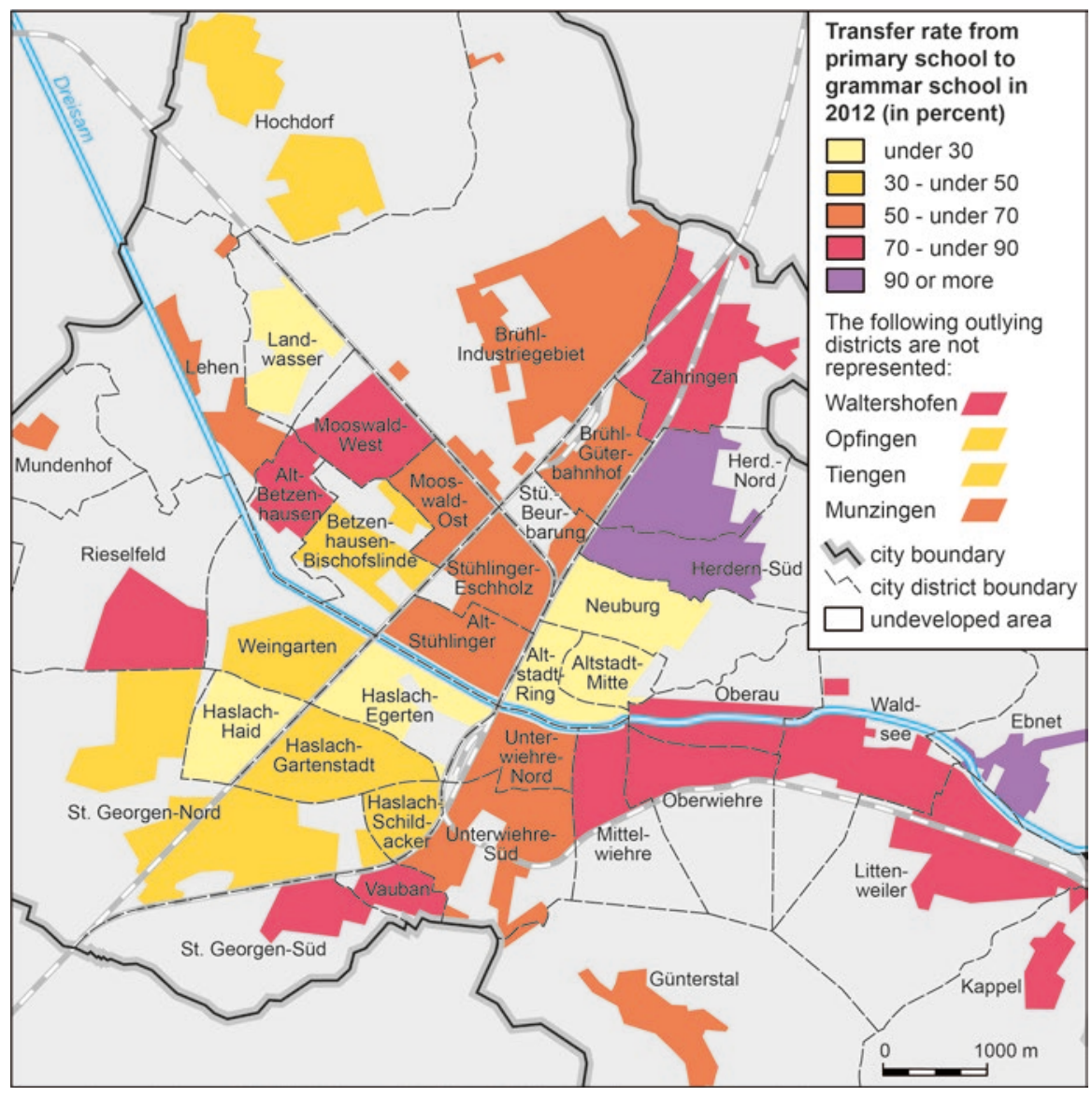

Fig. 7.5 Transfer rate from public primary school to grammar school in 2012 (Data: Stadt Freiburg, 2013, Tab. C1-4A). Source: Design by authors 
detailed data, it is difficult to conduct a geographical analysis, to evaluate individual schools, and to work out suitable measures for a particular school. In contrast to the situation in the U.S. and in many other countries, access to detailed educational data is restricted in Germany, and even anonymized data for individual schools or students is difficult to obtain. Obviously, it is a political decision not to publish more detailed data, as this might affect the image of individual schools and parents' choice of school for their children.

It was an exception that the City of Freiburg published the data on transfer rates from primary school to grammar school at the scale of urban planning districts, which we have represented in Fig. 7.5. Similar data is not publicly available for more recent years. From the map one sees that great inequalities exist between the urban planning districts. The primary schools located in Ebnet, Herdern-Nord, and Herdern-Süd have a transfer rate of over $90 \%$, whereas the rate is lower than $30 \%$ in Altstadt-Mitte, Altstadt-Ring, Haslach-Egerten, Haslach-Haid, Neuburg, and Landwasser. The transfer rates evidently correspond to the districts' socioeconomic profiles, that is, the highest rates are found in the urban planning districts with the most affluent residents. Moreover, the data confirms that on average more girls go on to grammar school than boys, and that the rate is higher among German students than among students without German citizenship. In 2007, 35\% of non-German students transferred from primary school to lower secondary school, $16 \%$ to intermediate secondary school, and only $7 \%$ to grammar school (Stadt Freiburg im Breisgau, 2008, p. 48). Although the share of non-German students who transfer to and graduate from grammar school has slightly increased during the past few years, students without German citizenship are still widely overrepresented among dropouts in lower secondary schools as well as in Freiburg's transition system.

\section{Voices from Students in the Transition System: Intersection of Problems at School and Out of School}

After policymakers launched the "Lernen vor Ort" program in Freiburg in 2010, we conducted qualitative interviews with a group of young people who were participating in the measures the transition system offered. In the 21 in-depth interviews, we followed a biographical approach in which we stimulated the interviewees to talk about their educational life up to the point where they accessed the transition system. The interviews became an integral part of the new monitoring the City of Freiburg was implementing as part of "Lernen vor Ort". It was the first time that qualitative data was gathered, and a biographical approach was applied to better understand - from an institutional perspective - why these people had not yet successfully completed their education. We interpreted the interviews following a qualitative content analysis, and constructed interview codes around indicators such as obstacles, networks, support, perceived failures, family background, geographical identification, and language knowledge. The results reveal not only individual 
aspects, but also structural obstacles and institutional failures, thus underlining the importance of interventions at the local scale. Asked about these self-perceived obstacles and their reasons for not completing school, the interviewees mentioned multiple difficulties in various fields. At an individual level, these young people had experienced all kinds of bullying, fights, verbal abuse, and discrimination.

Many classmates were not friendly. It was no fun. That's why I was not able to concentrate.

I was distracted ... For instance, they made fun of me because of the country I came from.

I come from Russia. So, I am (politically) a resettler. But not everybody understood this.

They were too young and, if I may say this, too stupid, as well. (Student, 2010)

The political agreement between Germany and many Eastern European countries allowed resettlement and German citizenship for people who were able to prove they had German ancestors. In the late 1980s and early 1990s, civil unrest and the problematic situation of many people in Russia spurred this type of migration to Germany. The unequal treatment of immigrants with German ancestors and other immigrants often resulted in tension between the two groups. At the same time, because the resettlers were politically considered to be German citizens, they were excluded from social services such as language classes, even though their knowledge of German was often insufficient. In the schools, political quarrels and decisions have a direct impact. Thus, students' language skills often depend on government regulations and policies. The hierarchical school system cannot adequately respond to this challenge, as traditionally a lack of language skills at a certain age has been linked to poor intellectual capacities rather than a foreign background. Consequently, the students concerned were provided with "easier" and lower-level education in lower secondary schools. Many students we interviewed said that the school system failed to adequately address their difficulties with speaking and writing in German. A lack of language skills leads to slower learning and understanding, but in school it is the curriculum, and not the teachers, who regulate the speed of learning. The German school system's hierarchical structure is thus a major weakness because it does not provide for additional support in learning the German language:

I am in Germany for six years, now. I was immediately sent to lower secondary school. It was difficult to learn the German language, because there was no special class where I could have learned it. And I was particularly shy then. I could not open up myself, because I did not speak the language. (Student, 2010)

Asked about help with learning the language, one student answered:

There was only a little bit of German lessons. They have taken me out of class from time to time and taught me a bit of grammar. I heard in other schools there is a special class for foreigners. But my parents did not know about it. So, they sent me right to lower secondary school. (Student, 2010)

Only a few respondents said they had the necessary support:

I was lucky to have a teacher who understood my potential. She helped me, she understood that the results (in terms of grades) were not due to me being stupid, but the fact that I didn't follow up, because I did not speak their language. If she had not supported me over the time when I had language difficulties, some time I would have stopped completely. (Student, 2010) 
Even at the grammar school level, students with poor German language skills are often overlooked and put in regular classes. For teachers, it is almost impossible to help these students while teaching the others in the same classroom at the same time. They would need appropriate teaching resources and specialized training. As a consequence, many students without an adequate knowledge of German are given something to keep them busy, rather than help with understanding the lessons.

Disruptions in personal biographies also play a major role in preventing people from completing school. This applies not only to experiences of international migration, but also to Germans who can look back on turbulent and geographically mobile biographies within Germany. In these complicated and sometimes dramatic cases, teachers play a crucial role. On the one hand, a teacher has to act as a social mediator and contact person for students with personal problems, whereas on the other hand he or she must transmit knowledge and skills and foster educational competition. The German school system is primarily oriented towards the latter, and any additional efforts in the realm of social care and welfare depend on the teacher's individual ethics and initiative.

I was at primary school when my parents divorced. And as a result, I could not learn anymore and so I had to repeat the first year. Then I continued until the fourth year and had a teacher's recommendation for transfer to intermediate secondary school. And my stepfather was beating me. Me and my sister. And this was reported to the police. But then I did not learn anymore and I started to hurt myself. And when teachers saw this, they said-well, they mentioned it, but said it in another way: There's no place for me at this school. (Student, 2010)

All kinds of tensions and problems in class create difficult learning environments. Some students spoke about daily chaos at school and a detrimental learning environment.

That was nothing for me [laughing]. The situation was chaotic. Many students never showed up in class. Some were smoking something in the schoolyard. Others were drunk. It was incredible. Teachers were stressed all the time. On some days, there were two students out of 16 in class. (Student, 2010).

This kind of problematic situation is sometimes a fertile ground for violence. Some students mentioned that others often hit and punched them due to their ethnic or national background-whether German or non-German. Social support was given only in rare and individual cases, often involving parents or supportive people from outside the school. A student who often came to school late negotiated a special agreement with her teacher that helped to discipline and motivate her. If she arrived late, the teacher would immediately call her mother, something which the student was anxious to avoid. Such successful examples seem to be relatively rare and only work well with additional backup outside the school, thus overcoming teachers' territorial and social limits.

In the interviews conducted with students in the transition system, it comes out very clearly that difficulties at school are often aggravated by intersecting barriers and handicaps, such as limited German language skills and lack of special support, personal or family problems, violence and (racist) discrimination. The reasons for 
the students' difficulties at school can be located partly in school and partly outside school. Similarly, potential support in overcoming these difficulties can be found both in school and in the out-of-school environment. Such support structures include friends and family members, social networks, and individual teachers with a personal commitment to helping students with particular difficulties. In the interviews, some students reported that they could draw upon support structures after school that were only barely connected to the school or even completely ignored by their teachers. There is also a lack of cooperation between politico-administrative institutions and schools. Thus, interviewees spoke about different nonconnected centers that are engaged in getting people into work and helping them overcome bureaucratic obstacles. From the perspective of the students in the transition system, there is no obvious connection between educational and social policies, and there is clearly a need to integrate and better coordinate the relevant actors and structures in order to provide effective support. The program "Lernen erleben in Freiburg" (LEIF) was designed to address this issue.

\section{Implementing the "Lernen Erleben in Freiburg" (LEIF) Project}

Through the national "Lernen vor Ort" program, the City of Freiburg was given funds to conduct the local project known as "Lernen erleben in Freiburg" (LEIF) from 2009 to 2014. The initiatives, activities, and achievements of LEIF are documented in local education reports and a set of complementary documents published by the City of Freiburg (Amt für Bürgerservice und Informationsmanagement der Stadt Freiburg im Breisgau, 2019; Stadt Freiburg im Breisgau, 2008, 2010, 2013, 2016, 2017). These sources enable one to trace how the project evolved over time, and to what extent it transformed the local educational landscape.

Prior to the start of the LEIF project, the Freiburg educational region (Bildungsregion Freiburg) was formally set up in 2006-08 as a network of 65 public and private schools in and around Freiburg. This network proved successful in attracting public (local, regional, and federal) funds and private financial support to conduct LEIF and other projects with a focus on schooling and education. With its first edition published in 2008, the Freiburg education report was a milestone, and it served as an important resource for educational monitoring, quality improvement, and preparing the subsequent applications for funding. In the preface of the first Freiburg education report (Stadt Freiburg im Breisgau, 2008), the authors explain that this type of educational monitoring (with reports to be published every 2 years) should provide a comprehensive source of data and information for planning activities to improve the quality of local schools. The education report's purpose is to guarantee transparency, and to provide data for comparing the present situation with previous years and with other locations. Accordingly, the report is meant to inform public and political debates and to enable evidence-based political decisions and interventions in the educational landscape of Freiburg. 
Funded within the framework of "Lernen vor Ort," LEIF sought to create better connections between the educational landscape and the students, together with their parents, taking into account the local setting and conditions in the various neighborhoods. During the first years of LEIF, a key priority was to focus on the difficulties of non-German students, and to develop strategies and instruments to give them efficient support and to better respond to their particular needs. This initiative was reinforced by the creation of the "Migration and Education" network (Netzwerk "Migration und Bildung") in September 2010 to help overcome the difficulties of non-German students as documented in the first Freiburg education report (Stadt Freiburg im Breisgau, 2008). Consequently, LEIF actors initiated and coordinated a social area analysis with a focus on migration and education to be started in 2011 (Stadt Freiburg im Breisgau, 2010, pp. 13-14). LEIF actors were also strongly concerned with supporting the transfer from primary school to suitable secondary education institutions. Here, they put particular emphasis on providing better information about the Freiburg educational landscape and the options for secondary education. This was the main aim when establishing the Freiburger Lupe (meaning "Freiburg magnifying glass"). This started as a leaflet but was later transformed into an Internet platform providing comprehensive and easily accessible information about educational choices in Freiburg.

From the following editions of the Freiburg education report, one learns that the priorities set for the LEIF initiatives shifted over time. In the beginning, the focus was on non-German students and the transfer from primary to secondary school. At the same time, LEIF was engaged in enhancing network activities between schools, and initiated a self-evaluation of schools (Selbstevaluation in Schulen; SEIS) using a tool provided by the Bertelsmann Foundation. The Freiburg education report of 2010 showed that the transfer rate from primary to intermediate secondary school or grammar school had risen among students from immigrant or poor families. Hence, LEIF set new priorities and put the transition system on the agenda, with the aim of supporting adolescents who dropped out of school before achieving any formal educational qualification, and who faced severe difficulties in finding an apprenticeship or a job (Stadt Freiburg im Breisgau, 2010, p. 107). In the third Freiburg education report (Stadt Freiburg im Breisgau, 2013), the authors set inclusion as a new priority. LEIF's rapidly shifting agenda reflects both changes that are highlighted in the national education reports and the fact that initiatives are usually organized as projects to be accomplished within a limited time frame. However, it is striking that the Freiburg education reports do not provide data at the level of individual schools, although their actors' mission is to work for more transparency in the local educational landscape. All in all, the series of Freiburg education reports serves both as evidence that LEIF has been very successful in its ongoing and past initiatives, and as a means of revealing new challenges to be addressed in the future.

LEIF's funding period was limited to 5 years, ending in 2014. Consequently, the competencies of the Regional Education Bureau (Regionales Bildungsbüro) and the LEIF initiative were combined, and permanently integrated in the institutional framework of the Stabsstelle Freiburger Bildungsmanagement in Autumn 2014 (Stadt Freiburg im Breisgau, 2017, pp. 4-5). LEIF's institutional integration into the 
education management structures of the City of Freiburg corresponds to the overall aim of the "Lernen vor Ort" program. In this light, "Lernen vor Ort" and LEIF can be seen as the great success story of a mission that has been fully accomplished. However, it is clear that the funded institutions and their representatives are not really in a position to critically assess the quality and impact of their own work. For this reason, in the following section, we suggest adopting a broader perspective, and taking a more critical stance toward LEIF's achievements and the transformation of educational landscapes in the "Lernen vor Ort" program.

\section{Limitations of the "Lernen vor Ort" Program and Its Implementation in Freiburg}

From the case of the Freiburg educational landscape, one gleans that ongoing monitoring based on educational statistics and reports helps to identify shortcomings and challenges in the education system, and to react with target-oriented measures and initiatives. However, the potential of an area-based approach for interventions to enhance educational opportunities and educational justice is not fully played out in the LEIF project. Because the role of local educational settings is stressed in both the Freiburg education reports and the series of interviews presented above (in the section on Voices from Students in the Transition System), it is hard to understand why there are not more initiatives and information on the microscale of individual schools and neighborhoods. For example, the Freiburger Lupe internet platform provides information about the educational opportunities in the city, with the aim of enhancing the educational participation and success of students, especially those from poor or immigrant families. However, the Freiburger Lupe and the Freiburg education report do not display relevant data or information at the level of individual schools. Not revealing the data for individual schools is problematic, as it makes it more difficult not only for the students and their parents to make well-informed educational choices that are not based on hearsay about particular schools' reputations, but also for stakeholders and decision-makers to develop target-oriented intervention measures in response to the specific needs of an individual school. And the counter argument that it might be necessary to preserve an individual school's anonymity to protect its reputation is not really convincing, as a reputation based on rumors is not better than a reputation based on data. It is a paradox if, on the one hand, local stakeholders and decision-makers require educational monitoring for the sake of transparency, whereas, on the other hand, they are allowed no access to the more detailed data that would be needed for well-informed interventions and the allocation of additional resources to support individual institutions.

Further, the national "Lernen vor Ort" program and its implementation in the "Lernen erleben in Freiburg" (LEIF) project and related local initiatives, such as the preparation of the Freiburg educational reports, reflect a general shift toward perception of the education sector as being increasingly exposed to competition and 
neoliberal instruments of intervention and transformation. Thus, educational institutions are expected to be subject to ongoing monitoring systems and quality improvement based on benchmarks and best practices. Although local stakeholders and decision-makers are involved in this type of educational governance, there tends to be a powerful top-down logic that works as an inherent driving force in the transformation of the educational landscape. This top-down logic is represented by the idea of a national program to be implemented in a local context. Thus, the local transformation process in education is embedded in overarching structures and discourses. This pattern is reflected in LEIF's changing priorities, which match the key topics in national education reports. Within a few years, the focus of national education reports shifted from immigrants (Avenarius et al., 2006; Maaz et al., 2016) to transfers after secondary level education (Klieme et al., 2008) and inclusion in education (Hasselhorn et al., 2014). The authors of the series of Freiburg education reports took up and addressed these key topics. Consequently, LEIF and the Freiburg educational reports do not highlight the specificities of the Freiburg case, but rather reflect an awareness of overarching national trends, and contribute to letting these trends trickle down to the local context.

\section{Conclusions}

Fragmented geographies of education on different territorial scales prevail in Germany, as do educational inequalities across demographic, economic, and sociocultural categories. As a result, educational opportunities depend to a considerable extent on family background and home environment, or, more broadly speaking, on educational settings that include both the out-of-school environment and the situation at school. Educational inequalities are closely related to, and often mutually reinforced by, socioeconomic disparities, which result in social reproduction. Not only students from poor families, but also students from immigrant families, are confronted with structural barriers in the German education system. Consequently, there is a need to better integrate educational and social policies, and to adopt an area-based approach for interventions with the aim of breaking the cycle of social and educational reproduction and paving the way for educational justice. This was more or less the starting point for the national "Lernen vor Ort" program that supported the work of "Lernen Erleben in Freiburg" (LEIF) and similar initiatives in other German cities, created in order to transform the local educational landscapes.

With the example of the "Lernen vor Ort" program and its implementation in Freiburg, one can underline both the potential of an area-based approach and the limitations of projects and initiatives set up to enhance educational opportunities. The LEIF initiative started a series of local education reports that are an important source of data for detecting shortcomings and inequalities in Freiburg, although data is not disclosed at the level of individual schools. Although LEIF initiated measures to improve educational opportunities, the guiding idea was not to create new educational structures, but to enhance communication and cooperation between 
educational institutions, and to provide students and their families with information about educational opportunities in Freiburg. An excellent example to illustrate this approach is the Freiburger Lupe, an internet platform with detailed information about the local educational landscape. In this case, it is up to the students and their parents to decide whether they want to use this educational resource. The problem is that this tool for empowerment in education does not necessarily reach those students who are most at risk, and sooner or later the Freiburger Lupe may widen the gap between students who benefit from this resource and those who do not get this kind of support. Finally, the actors of the LEIF initiative and the "Lernen vor Ort" program are confronted with the dilemma that enhancing educational opportunities does not mean reducing the potential for selection and exclusion that is inherent in the education system, especially when it comes to access or transfer to educational institutions. From this perspective, it is likely that the LEIF initiative and its permanent integration into the institutional framework of the Stabsstelle Freiburger Bildungsmanagement will contribute to stabilizing the fragmented geographies of education rather than reducing educational inequalities.

\section{References}

Amt für Bürgerservice und Informationsmanagement der Stadt Freiburg im Breisgau. (2019). Beiträge zur Statistik der Stadt Freiburg im Breisgau: Statistisches Jahrbuch 2019 [Contributions to the City of Freiburg's statistics: Statistical yearbook 2019]. Freiburg: Stadt Freiburg im Breisgau. Retrieved from https://fritz.freiburg.de/Bibliothek/statistik_veroeffentlichungen_Jahrbuch_2019.pdf

Astleithner, F., \& Hamedinger, A. (2003). Urban sustainability as a new form of governance: Obstacles and potentials in the case of Vienna 1. Innovation: The European Journal of Social Science Research, 16, 51-75. https://doi.org/10.1080/13511610304510

Avenarius, H., Baethge, M., Döbert, H., Hetmeier, H.-W., Klieme, E., Meister-Scheufelen, G., Rauschenbach, T., \& Wolter, A. (Eds.). (2006). Bildung in Deutschland 2006: Ein indikatorengestützter Bericht mit einer Analyse zu Bildung und Migration [Education in Germany 2006: An indicator-based report with an analysis of education and migration]. Bielefeld: W. Bertelsmann. Retrieved from https://www.bildungsbericht.de/de/bildungsberichteseit-2006/bildungsbericht-2006/pdf-bildungsbericht-2006/gesamtbericht.pdf

Baumert, J., \& Schümer, G. (2002). Family background, selection and achievement: The German experience. Improving Schools, 5(3), 13-20. https://doi.org/10.1177/136548020200500304

Baur, C. (2012). Schule, Stadtteil, Bildungschancen: Wie ethnische und soziale Segregation Schüler/-innen mit Migrationshintergrund benachteiligt [School, urban district, educational opportunities: How ethnic and social segregation is disadvantaging students with an immigrant background]. Bielefeld: transcript. https://doi.org/10.14361/transcript.9783839422373

Becker, B., \& Reimer, D. (2010). Vom Kindergarten bis zur Hochschule: Die Generierung von ethnischen und sozialen Disparitäten in der Bildungsbiographie [From kindergarten to college: The emergence of ethnic and social disparities in the educational biography]. Wiesbaden: Springer VS. https://doi.org/10.1007/978-3-531-92105-1

Bourdieu, P., \& Passeron, J.-C. (1977). Reproduction in education, society and culture (R. Nice, Trans.). Sage Studies in Social and Educational Change: Vol. 5. London: Sage.

Brümmer, F., Brüsemeister, T., Klausing, J., Lindner, M., Lüthi, K., Niedlich, S., Opper, M. K., \& Rädler, M. (Eds.). (2016). Kommunales Bildungsmanagement als sozialer Prozess: Studien 
$z u$ „Lernen vor Ort“ [Municipal education management as a social process: Studies on "local learning"]. Educational Governance: Vol. 33. Wiesbaden: Springer VS. https://doi. org/10.1007/978-3-658-12442-7

Butler, T., \& Hamnett, C. (2007). The geography of education: Introduction. Urban Studies, 44, 1161-1174. https://doi.org/10.1080/00420980701329174

Castel, R. (2009). Negative Diskriminierung: Jugendrevolten in den Pariser Banlieues [Negative discrimination: Youth rebellions in the Parisian banlieues] (T. Laugstien, Trans.). Hamburg: Hamburger Edition.

Donzelot, J. (2007). Stadtpolitik in Frankreich [Urban policy in France]. Informationen zur Raumentwicklung, 6, 371-380.

Esping-Andersen, G. (1990). The three worlds of welfare capitalism. Cambridge: Polity.

Esser, H. (2001). Integration und ethnische Schichtung [Integration and ethnic stratification] (Arbeitspapiere No. 40). Mannheim: Mannheimer Zentrum für Europäische Sozialforschung. Retrieved from http://www.mzes.uni-mannheim.de/publications/wp/wp-40.pdf

European Commission. (2019). PISA 2018 and the EU: Striving for social fairness through education. Luxembourg: Publications Office of the European Union. Retrieved from https:// ec.europa.eu/education/sites/default/files/document-library-docs/pisa-2018-eu_1.pdf

Grundgesetz für die Bundesrepublik Deutschland [Basic Law of the Federal Republic of Germany]. (2020, September 29). Germany.

Hanson Thiem, C. (2009). Thinking through education: The geographies of contemporary educational restructuring. Progress in Human Geography, 33, 154-173. https://doi. org/10.1177/0309132508093475

Hasselhorn, M., Baethge, M., Füssel, H.-P., Hetmeier, H.-W., Maaz, K., Rauschenbach, T., Rockmann, U., Seeber, S., Weishaupt, H., \& Wolter, A. (Eds.). (2014). Bildung in Deutschland 2014: Ein indikatorengestützter Bericht mit einer Analyse zur Bildung von Menschen mit Behinderungen [Education in Germany 2014: An indicator-based report with an analysis of people with disabilities]. Bielefeld: W. Bertelsmann. Retrieved from https://www.bildungsbericht.de/de/bildungsberichte-seit-2006/bildungsbericht-2014/pdf-bildungsbericht-2014/ bb-2014.pdf

Holloway, S. L., \& Jöns, H. (2012). Geographies of education and learning. Transactions of the Institute of British Geographers, 37, 482-488. https://doi.org/10.1111/j.1475-5661. 2012.00542.x

Klieme, E., Döbert, H., Baethge, M., Füssel, H.-P., Hetmeier, H.-W., Rauschenbach, T., Rockmann, U., \& Wolter, A. (Eds.). (2008). Bildung in Deutschland 2008: Ein indikatorengestützter Bericht mit einer Analyse zu Übergängen im Anschluss an den Sekundarbereich I [Education in Germany 2008: An indicator-based report with an analysis of transfers after the Secondary I level]. Bielefeld: W. Bertelsmann. Retrieved from https://www.bildungsbericht.de/de/ bildungsberichte-seit-2006/bildungsbericht-2008/pdf-bildungsbericht-2008/bb-2008.pdf

Maaz, K., Baethge, M., Brugger, P., Füssel, H.-P., Hetmeier, H.-W., Rauschenbach, T., Rockmann, U., Seeber, S., \& Wolter, A. (Eds.). (2016). Bildung in Deutschland 2016: Ein indikatorengestützter Bericht mit einer Analyse zu Bildung und Migration [Education in Germany 2016: An indicator-based report with an analysis of education and migration]. Bielefeld: W. Bertelsmann. Retrieved from https://www.bildungsbericht.de/de/bildungsberichte-seit2006/bildungsbericht-2016/pdf-bildungsbericht-2016/bildungsbericht-2016

Maaz, K., Artelt, C., Brugger, P., Buchholz, S., Kühne, S., Leerhoff, H., Rauschenbach, T., Rockmann, U., Roßbach, H.-G., Schrader, J., \& Seeber, S. (Eds.). (2020). Bildung in Deutschland 2020: Ein indikatorengestützter Bericht mit einer Analyse zu Bildung in einer digitalisierten Welt [Education in Germany 2020: An indicator-based report with an analysis of education in a digitized world]. Bielefeld: W. Bertelsmann. Retrieved from https://www. bildungsbericht.de/static_pdfs/bildungsbericht-2020.pdf

Meusburger, P. (1998). Bildungsgeographie: Wissen und Ausbildung in der räumlichen Dimension [Geography of education: Knowledge and education in the spatial dimension]. Heidelberg: Spektrum. 
Middendorff, E., Apolinarski, B., Becker, K., Bornkessel, P., Brandt, T., Heißenberg, S., \& Poskowsky, J. (2017). Die wirtschaftliche und soziale Lage der Studierenden in Deutschland 2016: 21. Sozialerhebung des Deutschen Studentenwerks—durchgeführt vom Deutschen Zentrum für Hochschul- und Wissenschaftsforschung [The economic and social status of students in Germany 2016: Social survey of the German National Association for Student Affairsconducted by the German Centre for Higher Education Research and Science Studies]. Berlin: Bundesministerium für Bildung und Forschung. Retrieved from http://www.sozialerhebung. de/download/21/Soz21_hauptbericht.pdf

Noreisch, K. (2007). Choice as rule, exception and coincidence: Parents' understandings of catchment areas in Berlin. Urban Studies, 44, 1307-1328. https://doi. org/10.1080/00420980701302320

OECD. (2020). Education policy outlook: Germany. Retrieved from http://www.oecd.org/education/policy-outlook/country-profile-Germany-2020.pdf

Parkinson, M. (1998). Combating social exclusion: Lessons from area-based programmes in Europe. Bristol, UK: Policy Press.

Raffe, D. (2008). The concept of transition system. Journal of Education and Work, 21, 277-296. https://doi.org/10.1080/13639080802360952

Ramos Lobato, I. (2019). Free primary school choice, parental networks, and their impact on educational strategies and segregation (Doctoral dissertation). Retrieved from https://hss-opus. ub.ruhr-uni-bochum.de/opus4/frontdoor/deliver/index/docId/6581/file/diss.pdf

Ramos Lobato, I., \& Groos, T. (2019). Choice as a duty? The abolition of primary school catchment areas in North Rhine-Westphalia/Germany and its impact on parent choice strategies. Urban Studies, 56, 3274-3291. https://doi.org/10.1177/0042098018814456

Schmidt, C. (2011). Krisensymptom Übergangssystem: Die nachlassende soziale Inklusionsfähigkeit beruflicher Bildung [Transition system as a symptom of crisis: Vocational education and its declining capacity for social inclusion]. Berufsbildung, Arbeit und Innovation—Dissertationen/Habilitationen: Vol. 22. Bielefeld: W. Bertelsmann. https://doi. org/10.3278/6004242w

Schreiber, V., Stein, C., \& Pütz, R. (2016). Governing childhood through crime prevention: The case of the German school system. Children's Geographies, 14, 325-339. https://doi.org/1 $0.1080 / 14733285.2015 .1048426$

Silver, H. (1994). Social exclusion and social solidarity: Three paradigms. International Labour Review, 133, 531-578.

Smith, I., Lepine, E., \& Taylor, M. (Eds.). (2007). Disadvantaged by where you live? Neighbourhood governance in contemporary urban policy. Bristol, UK: Policy Press. https://doi.org/10.2307/j. ctt9qgm1b

Stadt Freiburg im Breisgau. (2008). Bildung in Freiburg 2008: 1. Bildungsbericht der Stadt Freiburg im Breisgau [Education in Freiburg 2008: First education report of the City of Freiburg]. Freiburg: Stadt Freiburg im Breisgau. Retrieved from https://www.freiburg.de/pb/ site/Freiburg/get/paramsE1619277766/386901/Bildungsbericht2008.pdf

Stadt Freiburg im Breisgau. (2010). Bildung in Freiburg 2010: 2. Bildungsbericht der Stadt Freiburg im Breisgau [Education in Freiburg 2010: Second education report of the City of Freiburg]. Freiburg: Stadt Freiburg im Breisgau. Retrieved from https://www.freiburg.de/pb/ site/Freiburg/get/paramsE1495198538/386900/Bildungsbericht2010.PDF

Stadt Freiburg im Breisgau. (2013). Bildung in Freiburg 2013: 3. Bildungsbericht der Stadt Freiburg im Breisgau [Education in Freiburg 2013: Third education report of the City of Freiburg]. Freiburg: Stadt Freiburg im Breisgau. Retrieved from https://www.freiburg.de/pb/ site/Freiburg/get/paramsE266686385/572745/Bildungsbericht2013.pdf

Stadt Freiburg im Breisgau. (2016). Bildungsregion Freiburg: Erfahrungen aus zehn Jahren [Freiburg educational region: Ten years of experiences]. Freiburg: Stadt Freiburg im Breisgau. Retrieved from https://www.freiburg.de/pb/site/Freiburg/get/params_E-1509670590/1278359/ Broschuere_BildungsregionFreiburg_2006_2016.pdf 
Stadt Freiburg im Breisgau. (2017). Bildungsbericht 2017: 4. Bildungsbericht der Stadt Freiburg im Breisgau [Education in Freiburg 2017: Fourth education report of the City of Freiburg]. Freiburg: Stadt Freiburg im Breisgau. Retrieved from https://www.freiburg.de/pb/site/Freiburg/ get/params_E-1038942988/1157314/Bildungsbericht_2017.pdf

van Zanten, A. (2005). New modes of reproducing social inequality in education: The changing role of parents, teachers, schools and educational policies. European Educational Research Journal, 4, 155-169. https://doi.org/10.2304/eerj.2005.4.3.1

Walther, U.-J., \& Günther, S. (2007). Vom lernenden Programm zur lernenden Politik? Stand und Perspektiven sozialer Stadtpolitik in Deutschland [From learning program to learning policy? Status quo and perspectives of social urban policy in Germany]. Informationen zur Raumentwicklung, 6, 349-362.

Open Access This chapter is licensed under the terms of the Creative Commons Attribution 4.0 International License (http://creativecommons.org/licenses/by/4.0/), which permits use, sharing, adaptation, distribution and reproduction in any medium or format, as long as you give appropriate credit to the original author(s) and the source, provide a link to the Creative Commons license and indicate if changes were made.

The images or other third party material in this chapter are included in the chapter's Creative Commons license, unless indicated otherwise in a credit line to the material. If material is not included in the chapter's Creative Commons license and your intended use is not permitted by statutory regulation or exceeds the permitted use, you will need to obtain permission directly from the copyright holder.

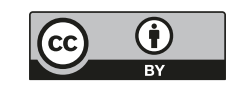

